UNTAG Law Review (ULREV)

Volume 3, Issue 2, November 2019, PP 178-187

ISSN 2549-4910 (online) \& ISSN 2579-5279 (print)

http://jurnal.untagsmg.ac.id/indeks.php/ulrev/indeks

www.fakhukum.untagsmg.ac.id

\title{
URGENCY OF SOCIALIZATION REGULATION REGARDING ESTABLISHMENT OF VILLAGE REGULATIONS
}

\section{Adhitya Widya Kartika}

Law Faculty, Universitas Pembangunan Nasional Veteran Jawa Timur

Email: adhityawidyakartika@ymail.com

\begin{abstract}
A country in carrying out its duties and authorities should have a legal basis which is the legality of its authority. This is reinforced by the state of Indonesia has included a rule of law on the constitution. While the village government is a part of the Indonesian state whose authority is one of which is regulated in the Law of the Republic of Indonesia Number 6 of 2014 concerning Villages. The village head is given the authority to form village regulations. Village regulations are expected to have solutions to village needs. Whereas in the formation of village regulations, their formation must be in accordance with the conditions of their formation. An obligation or regulation that is set to be enforceable or has a binding capacity should be regulated in a regulation which is a form of agreement between the government and the community. But there are provisions or regulations whose implementation rules are not to the last level. In fact there are provisions even though they have been enacted but there is no socialization so there are obstacles in their implementation. So it is important to socialize legal norms. Research on the urgency of socialization of legislation related to the formation of village regulations uses empirical legal research methods in which data can be obtained from the field or also referred to as socio legal research related to the formation and implementation of legislation related to village regulations.
\end{abstract}

Keywords: Formation of Norms, Village Regulations, Socialization

\section{INTRODUCTION}

Government is part of a country in other words the government is an element of a state. The government in carrying out its duties so that there is no arbitrariness, it must carry out its duties and authorities in accordance with the provisions in the legislation that has been enacted. Wirjono Prodjodikoro that combining the words of the state and law, that is, the term "rule of law" which means a state within its territory, firstly, all the state equipment, especially government equipment in its actions both to citizens and in their interrelationships each may 
not be arbitrary, but must pay attention to applicable legal regulations; and second, all people in social relations must comply with applicable legal regulations. ${ }^{1}$ This is reinforced by the state of Indonesia has included a rule of law on the constitution. Article 1 paragraph (3) of the 1945 Constitution of the Republic of Indonesia. The State of Indonesia because of its vast and diverse potential, the needs and problems of each region are not the same. Therefore the territory of Indonesia is further divided into smaller regions. The smallest area of the government system is the village. Because each region has its government, so does the village have its government called the village government. Therefore the village government is a part of the Indonesian state whose authority one of which is regulated in the Law of the Republic of Indonesia Number 6 of 2014 concerning Villages. The village head is given the authority to form village regulations. Village regulations are expected to have solutions to village needs. In addition, in the formation of village regulations, their formation must be in accordance with the conditions of their formation. An obligation or regulation that is set to be enforceable or has a binding capacity should be regulated in a regulation which is a form of agreement between the government and the community. However, there are provisions or regulations whose implementation rules have not reached the final level while the provisions in the laws and regulations must be implemented immediately.

Norms or provisions in statutory regulations come from various legal sources. There are legal sources that are material and formal. Basically, the source of law comes from the aspirations and needs of the community (in this case, the village), therefore it is important to gather ideas from the empirical and then the solution to the problem is applied to the empirical realm to solve the problem earlier. If a legal source is sources from an event that is in the community it means that the source is in the form of data on legal events in the community which then found a value. The value that arises earlier can have a forced force if the value was entered or represented in the form of norms. So, solutions to legal issues (as well as those of rights and obligations) that exist in society to be enforced must have or have passed the stage of establishing a norm so that solutions to legal problems in society and even the government can be applied in society and the government even the provisions or regulations or norms can be imposed in the community and government. Even to guarantee the binding of the provisions of a norm, sanctions within the norm are also applied so that those who are targeted are subject to norms or statutory provisions.

The explanation above brings the understanding that the solution that will be applied in the community and the government with regard to rights and obligations if to bind and have legal force it is necessary for the solution to be represented in the form of legal norms. The process of

1 Abdul Aziz Hakim. Negara Hukum dan Demokrasi di Indonesia. Pustaka Pelajar. Yogyakarta. 2011. Pg. 1819 
representation of solutions to legal norms (stages to legal norms) is a formal way or is a formal requirement that the laws and regulations are said to be valid and valid. Of course, the formal requirements for each of these laws and regulations differ from one statute to another, even at each level of the hierarchy of statutory regulations the formal stages for the formation of norms differ from one another.

The formal process is an important process of binding the targets of laws and regulations to the laws and regulations that will be formed. Van Apeldoorn, called the source of law in the formal sense because we only look at the ways and forms that gave birth to positive law without questioning where the contents of the rule of law. ${ }^{2}$ The tip of the formal process is the enactment of laws and regulations that have been formed. The process of enactment is important because to know about when a provision or norm in the legislation can be applied. Even after the promulgation it is also important for the socialization process to be bound by the target (bound party) in the provisions or norms in the legislation. This is important because the process of binding a value does not only need a formal process in the formation of laws and regulations but also in the process of how a provisions or norms in a law or regulation that can be applied without problems or at least minimize existing problems at the application stage. Likewise in the formation of village regulations in a village that must go through formal stages and after being validated and promulgated, of course there are stages of evaluation whether a regulation can be implemented or not whether effective or not. So the formal source of the formation of village regulations one of which is legislation in this case the source of the formation of laws and regulations need to be socialized so that the makers of legislation in the form of village regulations can understand it well so that the norms that are formed do not experience problems (at least suppress the problem). Therefore, in order to realize a target that is in a statutory regulation, it is certainly important to have a socialization so that the parties targeted in the law can understand it well. Although Article 95 of the Law of the Republic of Indonesia Number 12 of 2011 concerning Formation of Regulations and Regulations in the Sections of Disseminated Manuscripts, the Regulations of the Law that are disseminated must be copies of manuscripts that have been promulgated in the State Gazette of the Republic of Indonesia, Supplement to the State Gazette of the Republic of Indonesia, State Gazette of the Republic of Indonesia, Additional State Gazette of the Republic of Indonesia, Regional Gazette, and Regional News. However, it is important for an understanding in interpreting a provision or norm in a statutory regulation. Likewise in the formation of village regulations, it is necessary to have an understanding of how to form village regulations in accordance with the laws and regulations that have been enacted so that the formation of village regulations is

2 Van Apeldoorn. Inleiding tot de studie van het Nederlandsrecht. Translated Pengantar Ilmu Hukum. Jakarta. PT Pradnya Paramita. 1986. Page 67. 
also in accordance with the objectives of the provisions of the regulations governing village regulation (for example in the Law of the Republic of Indonesia Number 12 of 2011 concerning Formation of Regulations and Regulations related to its implementation).

Of course the formation of laws and regulations has been regulated in the Law of the Republic of Indonesia Number 12 of 2011 concerning Formation of Laws and Regulations but it is important for understanding to prevent multiple interpretations. Moreover, instructions for making village regulations included in the law itself namely the Law of the Republic of Indonesia Number 6 of 2014 concerning Villages which actually gives the village the authority to make village regulations in accordance with village needs will be less effective if there is no socialization regarding the implementation of the Law Law of the Republic of Indonesia Number 12 of 2011 concerning Formation of Regulations and Regulations. In the end, villages that did not understand the Law of the Republic of Indonesia Number 12 of 2011 concerning Formation of Laws and Laws of the Republic of Indonesia Number 6 of 2014 concerning Villages only made village regulations relating to annual implementation, even though many things could actually included in village regulations but have not dared to incorporate norms in village regulations and only socialization. Why is it necessary to socialize the Law of the Republic of Indonesia Number 12 of 2011 concerning Formation of Regulations and Regulations because the scope of the Law of the Republic of Indonesia Number 12 of 2011 concerning Formation of Regulations and Regulations includes matters relating to regulations made by the Village Head. Article 7 paragraph (1) of the Law of the Republic of Indonesia Number 12 of 2011 concerning Formation of Legislation Regulations that the Types and hierarchy of Legislation Regulations consist of: a. The 1945 Constitution of the Republic of Indonesia; b. Decree of the People's Consultative Assembly; c. Government Act / Regulation in Lieu of Law; d. Government regulations; Presidential decree; Provincial Regional Regulations; and Regency / City Regulations. Then in Article 7 paragraph (2) of the Law of the Republic of Indonesia Number 12 of 2011 concerning Formation of Legislation Regulations that the legal force of Legislation in accordance with the hierarchy referred to in paragraph (1). Then how is the connection with the Village Regulation made by the Village Head in Article 8 paragraph (1) that the Types of Legislation other than those referred to in Article 7 paragraph (1) include regulations determined by the People's Consultative Assembly, the House of Representatives, the House of Representatives Regional Representatives, the Supreme Court, the Constitutional Court, the Supreme Audit Board, the Judicial Commission, Bank Indonesia, Ministers, agencies, institutions, or committees which are at the same level formed by Law or Government by order of the Law, the Provincial Regional Representative Council, the Governor, Regency / City Regional People's Representative Council, Regent / Mayor, Village Head or equivalent. Therefore the Village Regulations are included in the scope of or included 
in the scope of the Law of the Republic of Indonesia Number 12 of 2011 concerning Formation of Laws and Regulations of the Republic of Indonesia Number 6 of 2014 concerning Villages.

\section{Formulation of the problem}

Exposure to the background, namely in the legal problem section, a problem statement can be drawn, namely how is the urgency of the socialization of legislation related to the formation of village regulations?

\section{Methods}

Research Articles in this journal are legal research articles. Research on the urgency of socializing legislation related to the formation of village regulations. Research on the urgency of socializing legislation related to the formation of village regulations uses empirical legal research methods in which data can be obtained from the field or also referred to as socio legal research. Therefore this analysis uses an approach to the analysis of laws and regulations and legal doctrines related to village governance, village regulations and the formation of laws or other regulations as long as they are related to the research on the urgency of socialization of legislation related to the formation of village regulations. This method uses the principles of qualitative analysis using primary and secondary data related to doctrines and legislation and then analyzed qualitatively and systematically drawn up and drawn conclusions. This type of research is empirical legal research is another approach model in researching in the field of law so that law is not only seen from the aspects of prescriptive and applied discipline but also the reality of law. ${ }^{3}$ This article is the result of empirical research focusing on villages in Sekaran Subdistrict, Lamongan Regency, East Java Province. The research was carried out related to the formation of Village Regulations. Then take data in the field with interviews and questionnaires related to the implementation of norms forming legislation, especially village regulations. The data is the primary data which can be obtained from the data collection process in the field. Besides using secondary data taken from the study of literature which later daata is used to analyze primary data. Secondary data used include doctrines or theories and legislation that can be taken from books and books related to legislation. After the data is collected or obtained then analyzed using a number of approaches including the doctrinal approach that is related to the opinions of experts and the regulatory approach related to the provisions relating to research. After that it is analyzed using a qualitative, systematic process and then conclusions are drawn.

\section{Discussion}

The village is one part of a country, as well as in the Unitary State of the Republic of Indonesia.

3 Banakar, Reza, MA Trave (editor). Theory and Method in Socio Legal Research: A Series published for The ONATI institute for the sociology of Law. Oxford and Portland Oregon. Hard Publishing 2005. 
Politically the village has the understanding as a government organization or organization of power that politically has a certain authority because it is part of the state government. ${ }^{4}$ How not, villages are part of the Indonesian state and their existence is strengthened by the existence of Article 18B of the 1945 Constitution of the Republic of Indonesia which states that the state recognizes and respects the customary law community units (note the phrase: recognize and respect community units customary law) along with their traditional rights as long as they are still alive and in accordance with the development of society and the principles of the Unitary State of the Republic of Indonesia, which are regulated in law. Meanwhile, according to Ter Haar, one of the characteristics of the unity of customary law communities is that the community is a regular and steady group, village communities are groups that adhere to certain values and norms and have their own government. ${ }^{5}$

This is what Ter Haar meant by the understanding of the unity of customary law communities, including villages that have their own government called village government. In addition, it was also strengthened by the separate regulation of villages, namely the Law of the Republic of Indonesia Number 6 of 2014 concerning Villages which was previously regulated simultaneously in a Law relating to regional government, namely the Law of the Republic of Indonesia Number 32 of 2004 concerning Local government. Even villages are given authority to regulate and manage their government affairs. This authority can be seen in the definition of the village. In Article 1 number 1 of the Law of the Republic of Indonesia that the village is a traditional village and village ... having the authority to regulate and manage government affairs, the interests of the local community based on community initiatives, rights of origin, and / or traditional rights recognized and respected in the system of government of the Unitary Republic of Indonesia. Whereas what is meant by the village government is the Village Head or what is referred to by another name assisted by the Village apparatus as an element of the Village Government organizer.

The village government, namely the village head, is given the authority to stipulate village regulations. This is regulated in Article 26 paragraph (2) letter d of the Law of the Republic of Indonesia Number 6 of 2014 concerning Villages, which previously had to be discussed and agreed with the Village Consultative Body. Processes related to the stages of the formation of Village Regulations include:

1. Village Regulations may not conflict with the public interest and / or higher legislation (Article 69 paragraph (2) Law of the Republic of Indonesia Number 6 of 2014 concerning Villages)

4 Mashuri Mashab, Politik Pemerintahan Desa di Indonesia, Prints I. PolGov, UGM Faculty of Social and Political Sciences, Yogyakarta, 2013, pp. 1-2,

5 Hanif Nurcholis, Pertumbuhan dan Penyelenggaraan Pemerintahan Desa, Erlangga, Jakarta, 2011. PAGE 16 
2. Village Regulations determined by the Village Head after being discussed and agreed with the Village Consultative Body (Article 69 paragraph (3) Law of the Republic of Indonesia Number 6 of 2014 concerning the Village)

3. Draft Village Regulation concerning the Village Revenue and Expenditure Budget, levies, spatial planning, and Village Government organizations must get an evaluation from the Regent / Mayor before it is determined to be a Village Regulation. (Article 69 paragraph (4) of the Law of the Republic of Indonesia Number 6 of 2014 concerning Villages).

4. The Village Regulation Draft must be consulted with the village community and the village community has the right to provide input to the Village Regulation Draft. (Article 69 paragraph (9) and (10) of the Law of the Republic of Indonesia Number 6 of 2014 concerning Villages).

5. Village regulations and Village Head regulations are promulgated in the Village Gazette and Village News by the Village secretary. (Article 69 paragraph (11) of the Law of the Republic of Indonesia Number 6 of 2014 concerning Villages).

6. In implementing village regulations, the village head establishes village head regulations as the implementing rules. (Article 69 paragraph (12) of the Law of the Republic of Indonesia Number 6 of 2014 concerning Villages).

The stages relating to the formation of village regulations actually provide flexibility with regard to the establishment of village regulations in addition to relating to annual routines, for example, with regard to the Village Expenditure Budget. The main thing is that the village regulations that will be formed or that have been formed must not be in conflict with the public interest or the provisions of higher statutory regulations. Thus the village regulations to be formed are not only products related to the Village Budget and Revenue but also can form village regulations regarding the needs that exist in the village. Thus, village regulations are not only intended to manifest or serve as a forum for village income and expenditure budgets, but can also serve as a forum for village needs (village government and village community for village progress) on laws or norms that will be applied to village regulations so that they respond or contain solutions to problems (law) that exist in the village or the village administration or the village community.

The needs of villages in Sekaran Subdistrict, Lamongan Regency, East Java Province in each village vary because the potential that can be increased in each village differs from one village to another. The implication of norms in the formation of village regulations (in general) is still limited to regulations related to the annual routine agenda while there are village provisions that have not been included in the form of norms such as village regulations. These provisions 
are limited to socialization although there are sanctions but the force applies differently if included in the form of norms. This is due to the lack of socialization related to the formation of regulations or legal products at the village level. Regulations related to village regulations are still limited to Law of the Republic of Indonesia Number 12 of 2011 concerning Establishment of Regulation on Legislation, Government Regulation of the Republic of Indonesia Number 43 of 2014 concerning Villages, Regulation of the Minister of Home Affairs of the Republic of Indonesia Number 111 of 2014 concerning Technical Guidelines for Regulations in the Village, and Guidelines for Drafting Village Regulation on 2014 Village Revenues and Expenditures (issued by the Village Administration Section, Lamongan District Secretariat in 2014). The Guideline for Drafting Village Regulation on 2014 Village Revenue and Expenditure Budget (issued by the Village Administration Section, Lamongan District Secretariat in 2014) also does not regulate in general, it only regulates the Village Revenue and Expenditure Budget.

The needs of a diverse village are of course issues related to the village also vary. The discussion related to the provisions relating to rights and obligations and subject to sanctions should be included in the container of the regulation with formal procedures that have been established by statutory regulations. This is because the obligation that is obligatory accompanied by sanctions requires the approval of the community (in this case represented by the Village Consultative Body (where community aspirations are collected here)). Besides the sanctions included in the provisions in the form of obligations can be applied to enforce the provisions of the obligation earlier. If not then theoretically the provisions are still in the form of values (such as the previous discussion of values that live in society which can also be referred to as a material source of law) and also do not guarantee that the procedure for establishing norms is in accordance with formal requirements and does not guarantee that a provision is binding or have a normative binding capacity. Material sources of law are community factors that influence the formation of law. ${ }^{6}$ Formal legal sources are the places or sources from which rules get legal force, related to the form or way that causes the rules of the law to be formally applied. ${ }^{7}$ This can be due to lack of human resource knowledge and lack of socialization related to the formation of village regulations. Even though the Act that was based on was already enacted but it does not guarantee that there is an understanding so that this can also result in less harmonization of the law. Socialization and training here are expected to be necessary or important so that the purpose and objectives of a statutory regulation that has been enacted earlier went well. In addition, if there is adequate human resource capacity, at least it can improve the quality of village regulations that will be made

6 NE Algra Et.al, Mula Hukum, Bandung, Binacipta, 1983, pp. 16.

7 Soedikno Mertokusumo, Mengenal Hukum Suatu Pengantar, Yogyakarta, Liberty, 1986, pp. 71, 
later. Therefore, because the village is the smallest region or region, the closest to the community, is considered to better understand the needs of the community and its region, and is the closest milestone to the people for the purpose of the state, it can help to realize the state's goals at the village level. Jam, if there is an understanding, it will increase the level of harmonization of the law (especially laws and regulations).

\section{Conclusion}

The need for socialization and training is related to the formation of legislation (especially regarding the formation of village government legal products, and more specifically related to the formation of village regulations). Even though the Act that was based on was already enacted but it does not guarantee that there is an understanding so that this can also result in less harmonization of the law. Socialization and training here are expected to be necessary or important so that the purpose and objectives of a statutory regulation that has been enacted earlier went well. In addition, if there is adequate human resource capacity, at least it can improve the quality of village regulations that will be made later.

\section{References}

Abdul Aziz Hakim. The rule of law and democracy in Indonesia. Student Library. Yogyakarta. 2011.

Banakar, Reza, MA Trave (editor). Theory and Method in Socio Legal Research: A Series published for The ONATI institute for the sociology Law. Oxford and Portland Oregon. Hard Publishing. 2005.

Hanif Nurcholis. Growth and Implementation of Village Governance. Erlangga Jakarta. 2011.

Mashuri Mashab. Politics of Village Governance in Indonesia. Matter I. PolGov. UGM Faculty of Social and Political Sciences. Yogyakarta. 2013.

NEAlgra. Et.al. Beginning of Law. Bandung. Binacipta. 1983.

Soedikno Mertokusumo. Know the Law of An Introduction. Yogyakarta. Liberty. 1986.

Van Apeldoorn. Inleiding tot de studie van het Nederlandsrecht. Translated Introduction to Law. Jakarta. PT Pradnya Paramita. 1986.

The 1945 Constitution of the Republic of Indonesia.

Law of the Republic of Indonesia Number 12 of 2011 concerning Formation of Regulations and Regulations, Republic of Indonesia State Gazette of 2011 Number 82 , Gazette of the Republic of Indonesia Number 5534. 
Law of the Republic of Indonesia Number 32 of 2004 concerning Regional Government, Gazette of the Republic of Indonesia Year 2004 Number 125, Supplement to State Gazette of the Republic of Indonesia Number 4437.

Law of the Republic of Indonesia Number 6 of 2014 concerning Villages, Republic of Indonesia State Gazette of 2014 Number 7, Additional Republic of Indonesia State Gazette Number 5495.

Government Regulation of the Republic of Indonesia Number 43 of 2014 concerning Villages, Republic of Indonesia State Gazette of 2014 Number 123, Additional Republic of Indonesia State Gazette Number 5539.

Regulation of the Minister of Home Affairs of the Republic of Indonesia Number 111 of 2014 concerning Technical Guidelines for Regulations in the Village, State Gazette Indonesia 2014 Number 2091.

Guidelines for Drafting Village Regulation on 2014 Village Budget and Revenue (issued by the Village Administration Section, Lamongan District Secretariat Year 2014). 